\title{
An Investigation into CIGS Thin-Films Solar Cell P2 Layer Scribing Depth and Width Using Different Laser Process Parameters
}

\author{
Dyi-Cheng Chen, ${ }^{1}$ Ming-Fei Chen, ${ }^{2}$ and Ming-Ren Chen ${ }^{1}$ \\ ${ }^{1}$ Department of Industrial Education and Technology, National Changhua University of Education, Changhua 500, Taiwan \\ ${ }^{2}$ Department of Mechatronics Engineering, National Changhua University of Education, Changhua 500, Taiwan
}

Correspondence should be addressed to Dyi-Cheng Chen; dcchen@cc.ncue.edu.tw

Received 13 November 2014; Revised 25 April 2015; Accepted 4 May 2015

Academic Editor: Sergi Gallego

Copyright (c) 2015 Dyi-Cheng Chen et al. This is an open access article distributed under the Creative Commons Attribution License, which permits unrestricted use, distribution, and reproduction in any medium, provided the original work is properly cited.

\begin{abstract}
This study will be about UV (355 nm) laser processing system as a carrier. It studied electrode insulated characteristic using laser direct forming for CIGS solar cell technology P2 layer of stainless steel. It explored the impact of this process on the way to stainless steel substrate P2 film sizes using its laser different focus position, energy density, and scanning velocities. According to the experiment results, the scribing results are straight line and larger width under minus leave perpendicularity and positive leave perpendicularity and the laser scanning velocities at $10 \sim 1000 \mathrm{~mm} / \mathrm{s}$ underline width about $0.96 \mu \mathrm{m} \sim 1.07 \mu \mathrm{m}$. The experiment results confirm that the laser apparatus is effective when applied to a stainless steel CIGS solar cell P2 layer.
\end{abstract}

\section{Introduction}

The energy is the important elements that the mankind depends on to support the family now. Membrane processes have the important role which raised the efficiency and lowered costs of solar cell material using laser process. The fabrication of the P2 layer in CIGS solar cells is based primarily on mechanical methods. It using laser processing to be reach best accuracy and size demand for mechanical equipment, laser processing is rapid, processing line wide relatively small and edge chip fewer advantages [1-3]. Jafari et al. [4] show that Tin on stainless steel substrates has a good capability for tokamak first wall due to its fine grain structure, high reflectivity, and hardness property. Li et al. [5] used a novel process method for the fabrication of DARC consisting of $\mathrm{SiN}_{x}: \mathrm{H}$ using PECVD and $\mathrm{SiO}_{2}$ films deposited using electron-beam evaporation. Walker et al. [6] proposed a new triple-junction solar cell (3J) exploiting the highly absorptive I-III-VI chalcopyrite $\mathrm{CuInSe}_{2}$ material as an alternative to III-V semiconductor 3J solar cells. Patidar et al. used monodispersed $\mathrm{ZnO}$ nanoparticles to fabricate $\mathrm{P} 3 \mathrm{HT} / \mathrm{ZnO}$ solar cells [7]. S. Zhao and C. Zhao [8] used transmission electron microscopy to observe the microstructure of boundaries between the matrix and G.P. zone in Ti-rich Ni-Ti alloy. Hsu et al. [9] developed a model using interpretive structural modeling (ISM), benefits, opportunities, costs, and risks (BOCR), and fuzzy analytic network process (FANP) to aggregate the opinions of experts in evaluating available solar cell technologies.

Huang et al. [10] developed a nanooxidation and wet etching technique to produce nanostructures on TiAlN film. Krishna et al. [11] proposed a new technique for the measurement of solar cell blanket temperature. The enhanced solar cell efficiency in multilevel rectangular, arbitrary gratings by Lin and Phillips can be attributed to improved optical coupling and light trapping across the solar spectrum [12]. Zhao and Jiang [13] studied the room temperature UV emission of $\mathrm{ZnO}$ films with various defect densities fabricated using a $\mathrm{KrF}$ laser irradiation process. Chen et al. [14] simulated the Gaussian distribution of laser irradiation on the preprocessor structure. A UV laser processing system produced micropatterns on ITO thin films to identify the conditions that could damage the substrates. Dai et al. [15] 


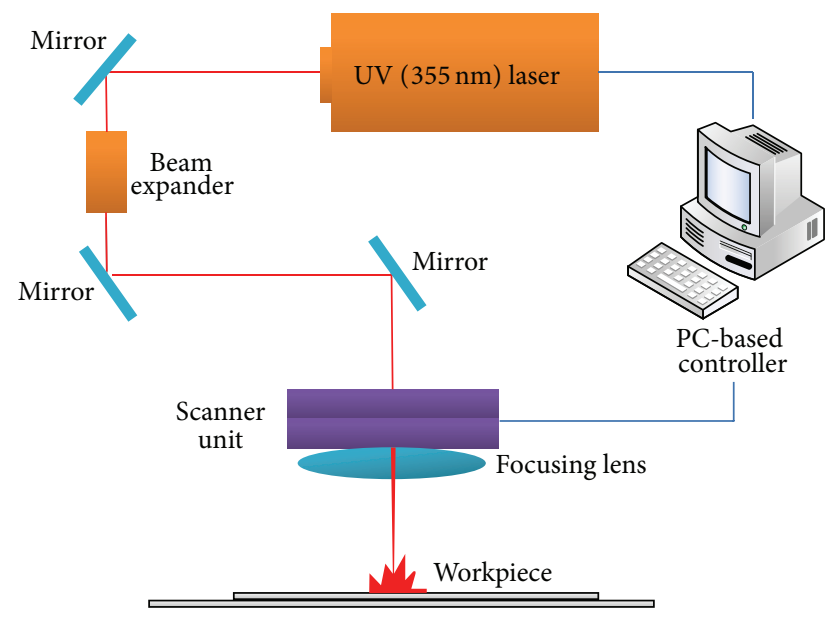

FIGURE 1: Illustration of laser process route [16].

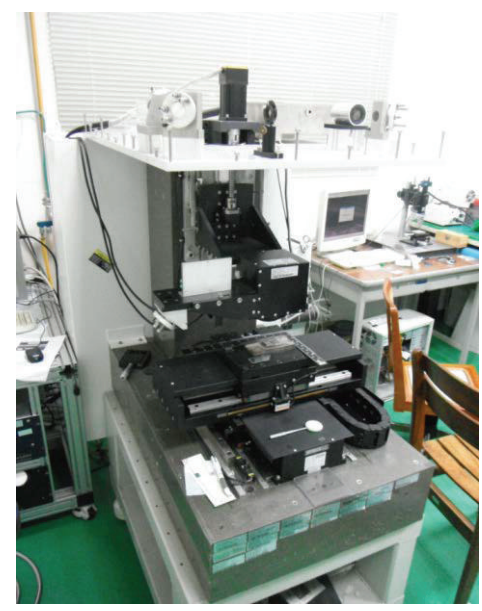

FIGURE 2: UV laser processing machine of the study laboratory [16].

presented a new approach to the development of GaN-based devices using the $157 \mathrm{~nm}$ DUV laser for microfabrication.

D. Chen and M. Chen [16] used ANSYS simulation software for the analysis of a UV (355-nm) laser processing system. According to the simulation results, the laser function time was $135 \mu \mathrm{s}$, the UV laser was $0.5 \mathrm{~W}$, and the P2 layer thin films were removed. Furthermore the maximum temperature at the surface of the material reached $2795^{\circ} \mathrm{C}$ using laser power of $0.5 \mathrm{~W}$, at which point the $\mathrm{P} 2$ layer material reached gasification temperature. The study focus was increasing laser scribing P2 layer phenomena understandability. The experiment results confirmed that the laser apparatus is effective when applied to a stainless steel CIGS solar cell P2 layer.

\section{Experimental Principle and Materials}

Figure 1 presents the laser process route. The UV laser primarily applies a high accuracy microelectronic product, semiconductor, LED, and LCD process. Figure 2 presents the
UV laser processing machine used in this study. A glass base plate of stainless steel was used in this study. The CIGS plates films have $\mathrm{SiO}_{2}$ layer, molybdenum electrode, CIGS absorbed layer, CdS buffered layer, i-ZnO penetrate light layer, TCO front electrode, $\mathrm{MgF}$ resisting reflected materials, and direct electrode materials. Figure 3 presents a diagram of the laser solar cell film. The diagram included P1, P2, and P3 layer for solar cell film materials.

\section{Experimental Procedure}

This study uses laser UV $(355 \mathrm{~nm})$ for the vehicle that used CIGS thin-film solar cells in the P2 layer scribing processing. The first stage was the characterization of the laser and laser system parameters. The second stage involved preparation of materials. Sputtering and chemical deposition were used in the fabrication of specimens. The third stage involved laser scribing of the $\mathrm{P} 2$ layer by altering the focus position, energy density, and scanning velocity. A 3D confocal laser scanning microscope was used to measure the width and depth of P2 layer.

\section{Results and Discussion}

Lasers can be used to scribe the P2 layer in CIGS thin-film solar cells; the main allows the laser heat source to remove molten layer P2 to achieve the insulation effect. But they cannot be used to remove the $\mathrm{SiO}_{2}$ film.

4.1. Scribing Results at Different Focus Position. The studies understand different situations of focusing position for workpiece scribing influence. In the experiment, scanning velocity is fixed and laser pulse frequency is fixed at $40 \mathrm{kHz}$ and laser energy is fixed at $0.4 \mathrm{~W}$ which change focus position to scribing specimen. We employed a confocal microscope to examine the results of scribing. Figure 4 shows focus position, that is, (a) perpendicularity, (b) minus leave perpendicularity, and (c) positive leave perpendicularity. From scribing results, obvious laser scribing width and depth, respectively, can be seen: (a) $W=29.481 \mu \mathrm{m}$ and $h=5.215 \mu \mathrm{m}$, (b) $W=$ $71.326 \mu \mathrm{m}$ and $h=0.950 \mu \mathrm{m}$, and (c) $W=67.522 \mu \mathrm{m}$ and $h=0.987 \mu \mathrm{mm}$. It can hit through P2 layer when energy gives $0.05 \mathrm{~W}$, because UV laser machine is very unstable when having lower energy and scribing line produces heat influence area and smaller line width as shown in Figure 4(a). The scribing results are straight line and larger width under minus leave perpendicularity and positive leave perpendicularity as shown in Figures 4(b) and 4(c).

4.2. Scribing Results Obtained Using Various Energy Density Levels. We employed a confocal microscope to examine the results of scribing with the following laser energy levels: (a) $0.4 \mathrm{~W}$, (b) $0.5 \mathrm{~W}$, (c) $0.6 \mathrm{~W}$, and (d) $0.7 \mathrm{~W}$. Figure 5 shows EDS analysis results after scribing the P2 membrane layer with a UV laser set at various energy density levels. As shown in Figure 5, a large number of granules can be seen along the edge due to the numerous materials with which the P2 layer is composed. It can be seen that UV laser process produced 


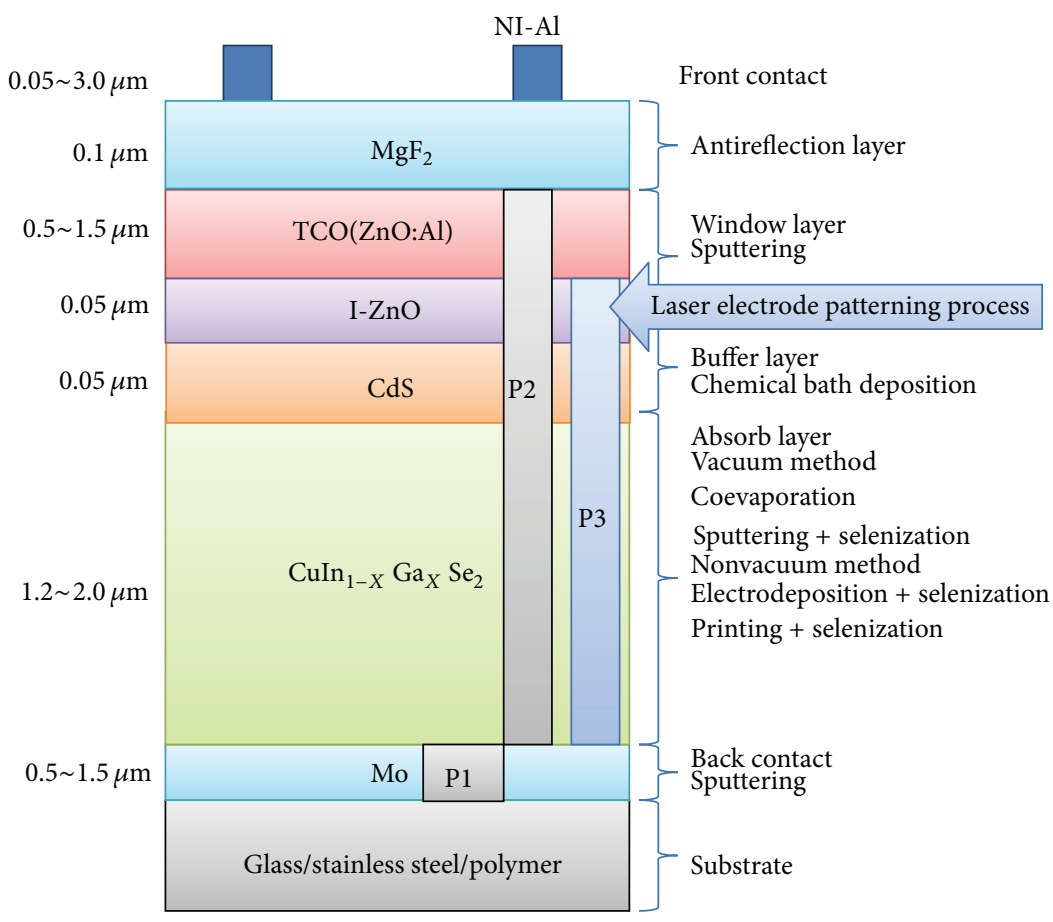

Figure 3: Diagram of the laser solar cell film [16].
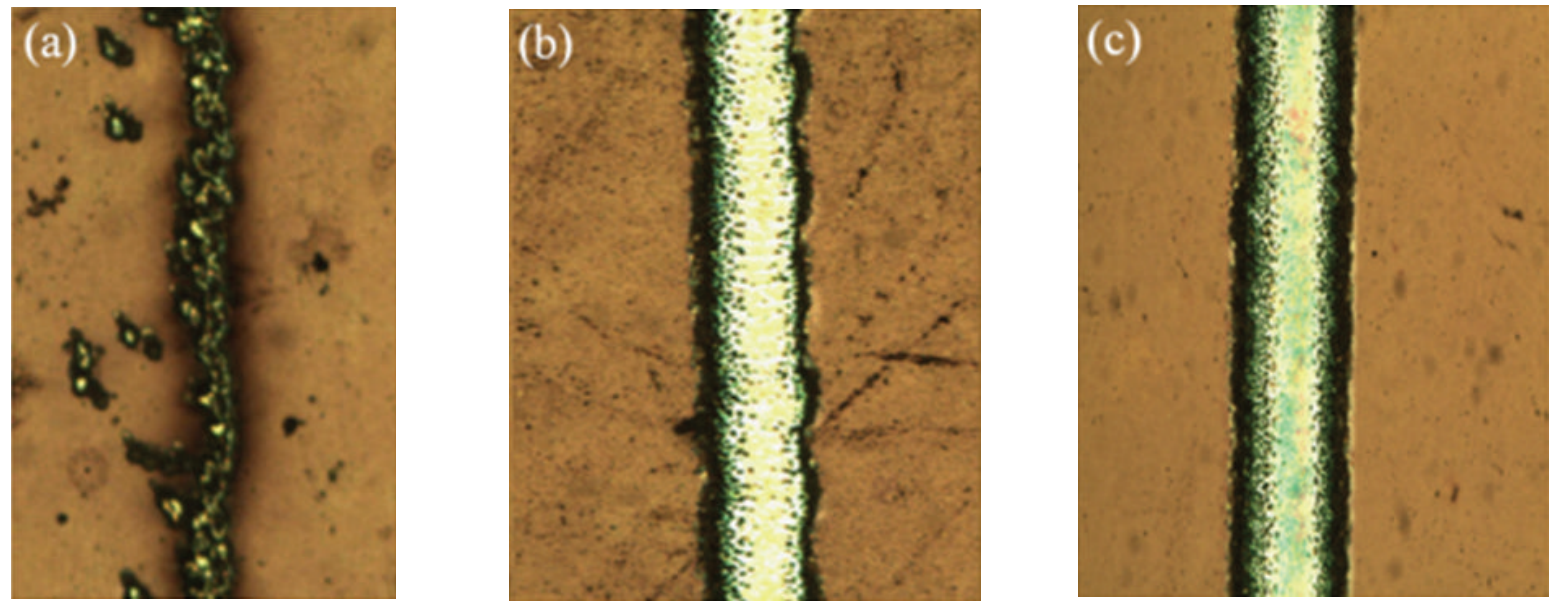

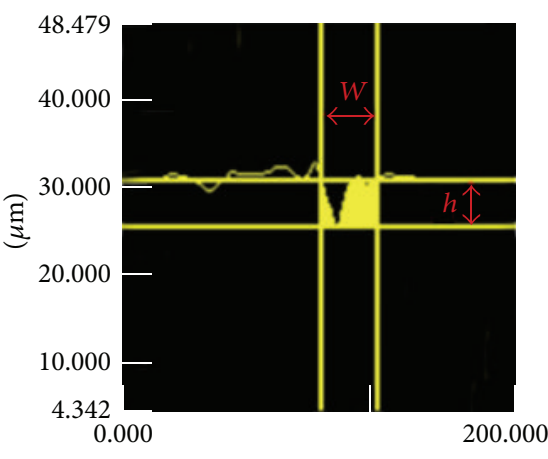

$(\mu \mathrm{m})$

(a)

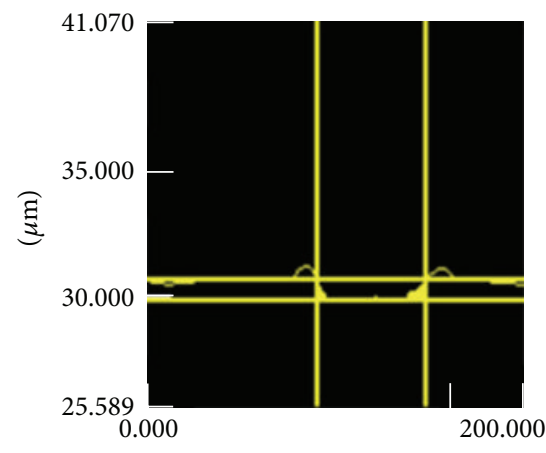

$(\mu \mathrm{m})$

(b)

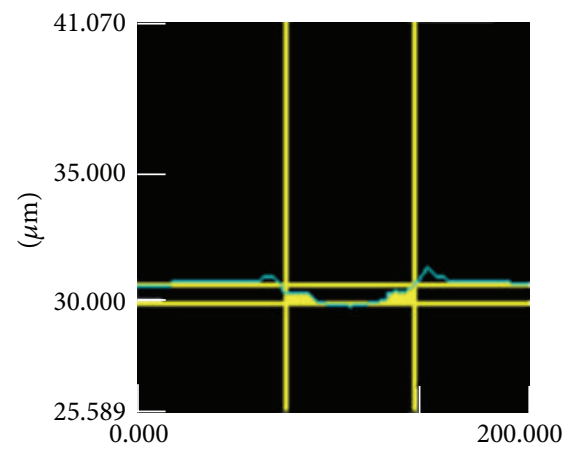

$(\mu \mathrm{m})$

(c)

FIgURE 4: UV laser focus position. (a) Perpendicularity, (b) minus leave perpendicularity, and (c) positive leave perpendicularity. 

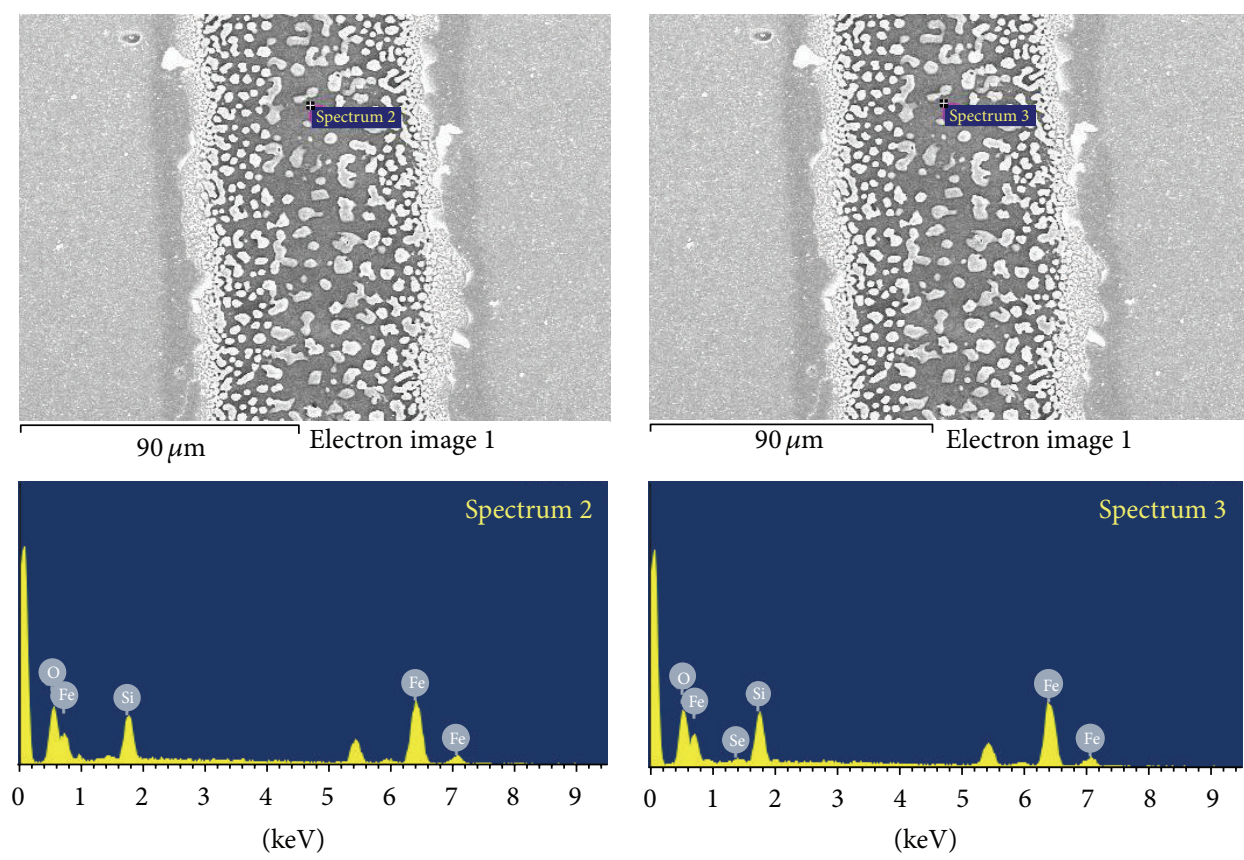

Full scale 1402 cts cursor: 0.000

Full scale 1402 cts cursor: 0.000

(a) Laser energy $0.4 \mathrm{~W}$. Atomic $\% \mathrm{O}=41.70, \mathrm{Si}=13.21$, $\mathrm{Fe}=45.08$

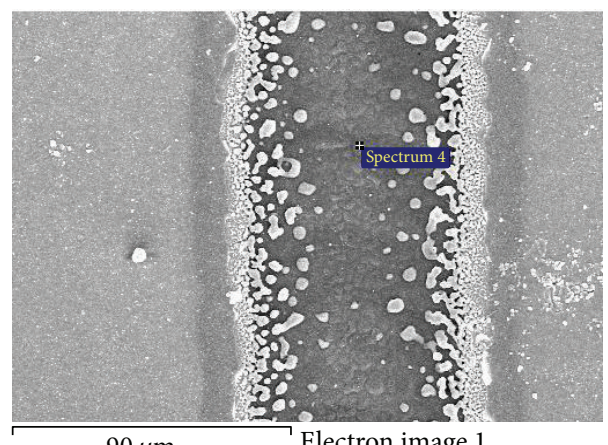

$\mathrm{Fe}=44.45, \mathrm{Se}=0.70$

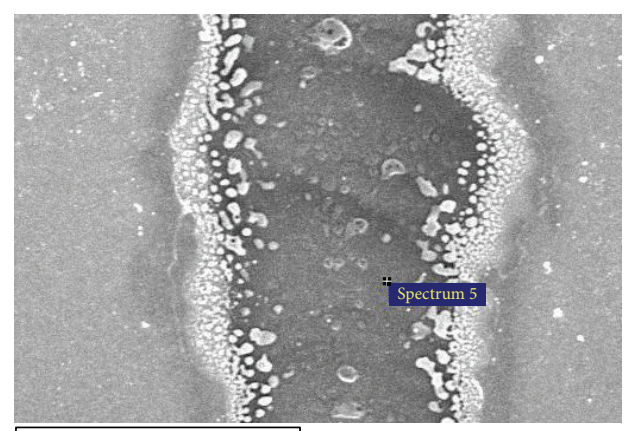

$90 \mu \mathrm{m}$

Electron image 1

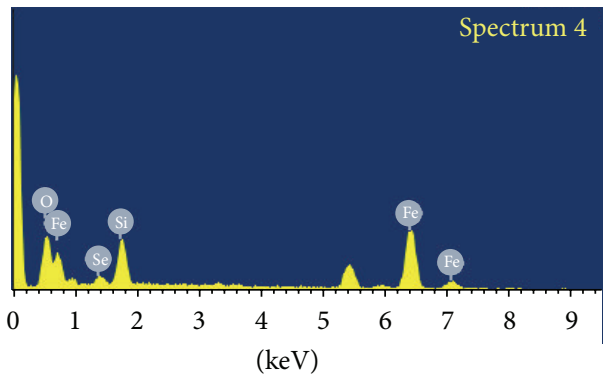

Full scale 1402 cts cursor: 0.000

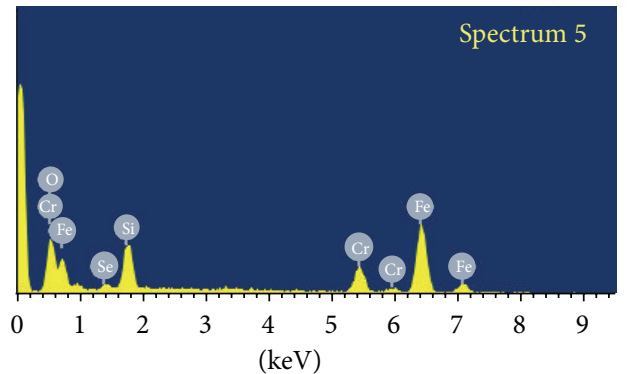

Full scale 1402 cts cursor: 0.000

(c) Laser energy 0.6 W. Atomic $\% \mathrm{O}=42.19, \mathrm{Si}=12.90$, $\mathrm{Fe}=43.16, \mathrm{Se}=1.74$

(d) Laser energy 0.7 W. Atomic\% O = 36.97, $\mathrm{Si}=11.68$, $\mathrm{Cr}=9.30, \mathrm{Fe}=41.07, \mathrm{Se}=0.98$

FIGURE 5: Scribing P2 layer membrane composition analysis result using different UV laser energy density.

$\mathrm{Cr}, \mathrm{Fe}$, and Se chemical composition because $\mathrm{SiO}_{2}$ penetrate rate is very similar to glass and induced $\mathrm{Cr}$ and $\mathrm{Fe}$ chemical elements.

4.3. Scribing Results Obtained at Various Scanning Velocities. Figure 6 used various scanning velocities for UV laser scribing P2 layer. The figure used positive leave perpendicularity and frequency is fixed at $60 \mathrm{kHz}$ and laser energy is fixed at $0.6 \mathrm{w}$. The study only changes laser scribing velocity to finish the specimen depth and width; it can be seen that no larger difference result using CCD microscope to watch specimen was found. 


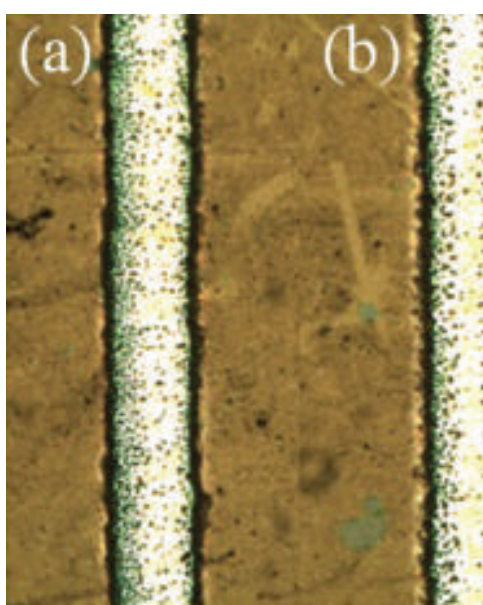

(a) $100 \mathrm{~mm} / \mathrm{s}$

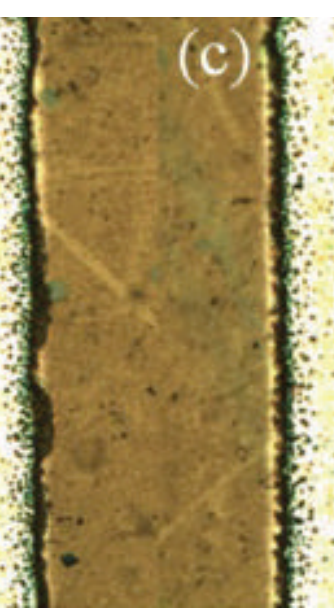

(c) $300 \mathrm{~mm} / \mathrm{s}$

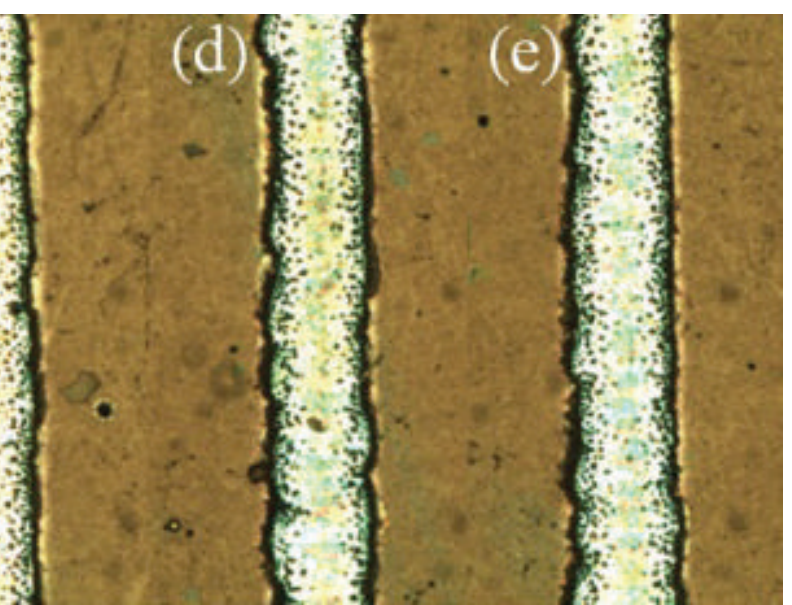

(d) $400 \mathrm{~mm} / \mathrm{s}$

(e) $500 \mathrm{~mm} / \mathrm{s}$

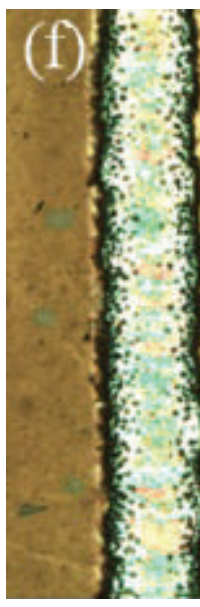

(b) $200 \mathrm{~mm} / \mathrm{s}$

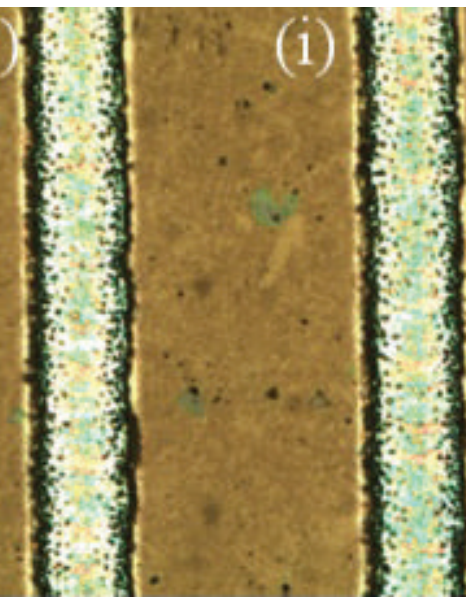

(h) $800 \mathrm{~mm} / \mathrm{s}$

(i) $900 \mathrm{~mm} / \mathrm{s}$

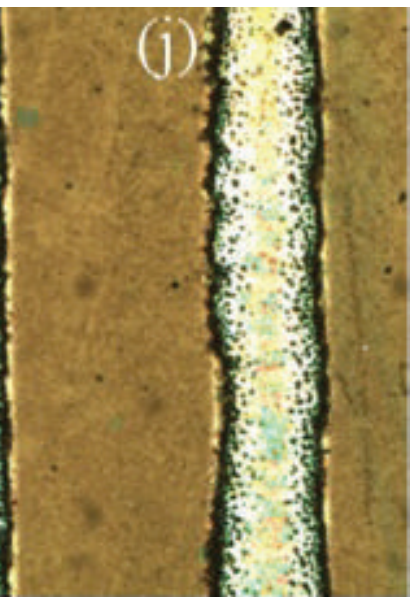

(g) $700 \mathrm{~mm} / \mathrm{s}$

(j) $1000 \mathrm{~mm} / \mathrm{s}$

FIGURE 6: UV laser scribing P2 layer at different scan velocity.

The laser scribing has finished 3D confocal microscope to measure the specimen. Figure 7 shows UV lasers using different scanning velocities scribing P2 film on 3D confocal microscope, including $100 \sim 900 \mathrm{~mm} / \mathrm{s}$, respectively. No obvious influence on depth and width for different scanning velocities can be seen.

Figure 8 shows relationship diagram of UV laser scanning velocities and underline depth. It can be seen that laser scanning velocities at $10 \sim 1000 \mathrm{~mm} / \mathrm{s}$ underline width about $0.96 \mu \mathrm{m} \sim 1.07 \mu \mathrm{m}$.

\section{Conclusion}

This study used UV laser to scribe on CIGS thin-film P2 layer. The simulation and experiment obtained the following several conclusions.

(1) The scribing results are straight line and larger width under minus leave perpendicularity and positive leave perpendicularity.
(2) UV laser process produced $\mathrm{Cr}, \mathrm{Fe}$, and Se chemical composition because $\mathrm{SiO}_{2}$ penetrate rate is very similar to glass and induced $\mathrm{Cr}$ and $\mathrm{Fe}$ chemical elements.

(3) The laser scanning velocities at $10 \sim 1000 \mathrm{~mm} / \mathrm{s}$ underline width about $0.96 \mu \mathrm{m} \sim 1.07 \mu \mathrm{m}$.

The experiment results confirm the effectiveness of the laser apparatus when applied to a stainless steel CIGS solar cell P2 layer.

\section{Conflict of Interests}

The authors declare that there is no conflict of interests regarding the publication of this paper.

\section{Acknowledgments}

The authors gratefully acknowledge the financial support of the National Science Council of the Republic of China under Grant no. NSC 101-2623-E-018-002-ET. 

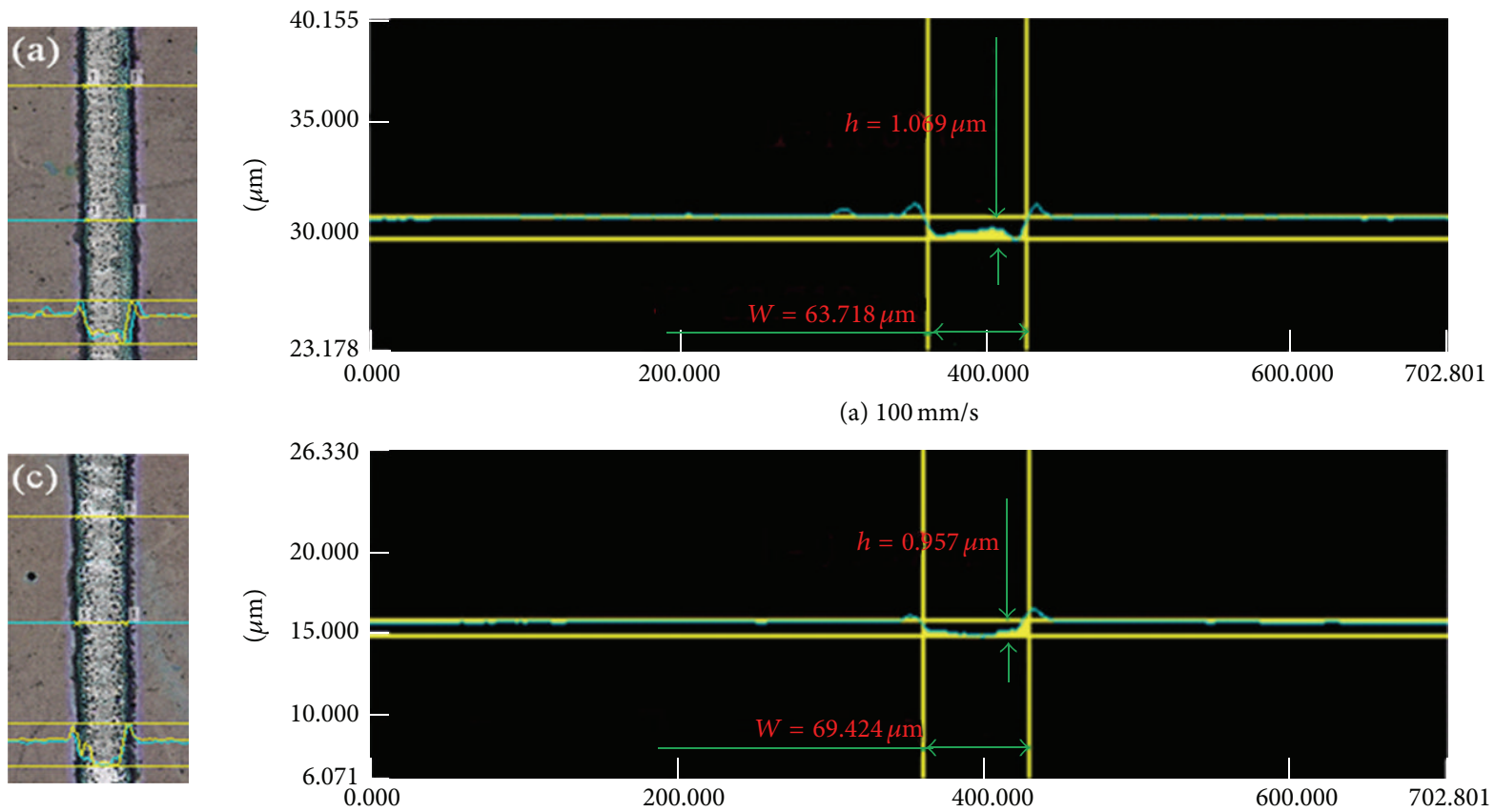

a) $100 \mathrm{~mm} / \mathrm{s}$
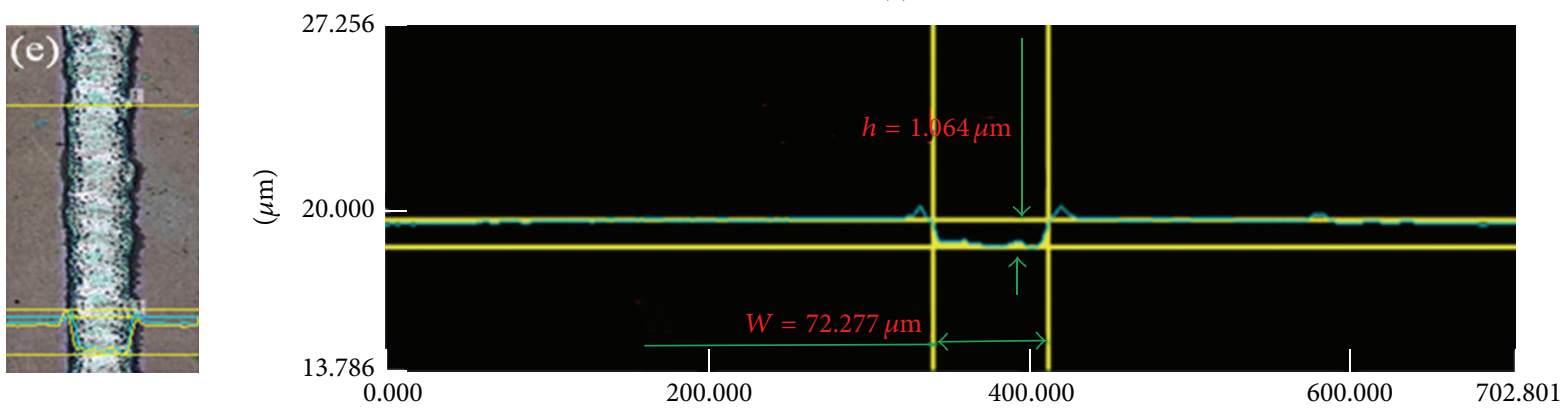

(e) $500 \mathrm{~mm} / \mathrm{s}$
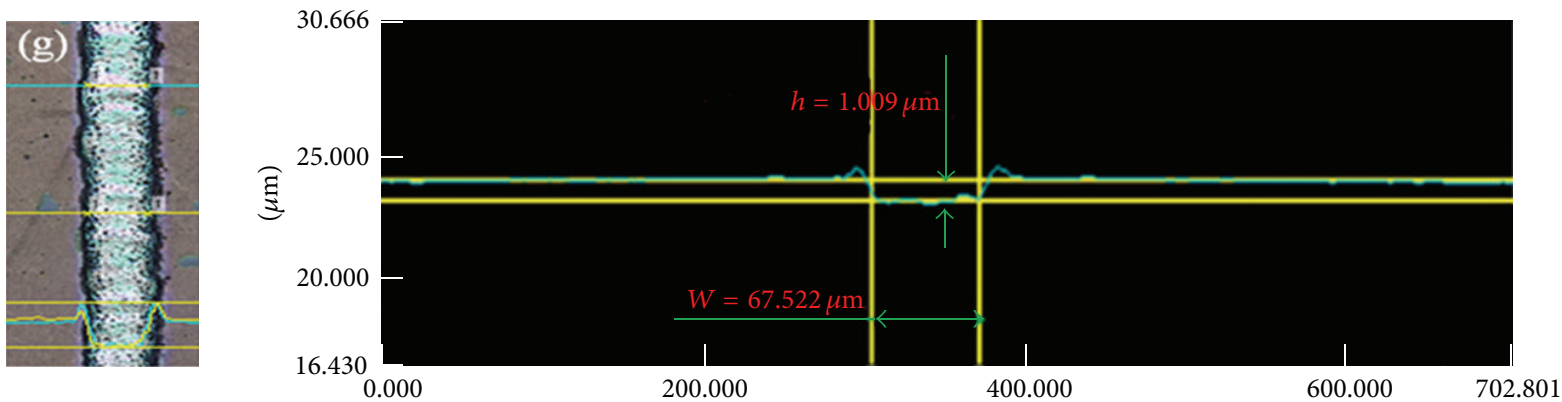

(g) $700 \mathrm{~mm} / \mathrm{s}$
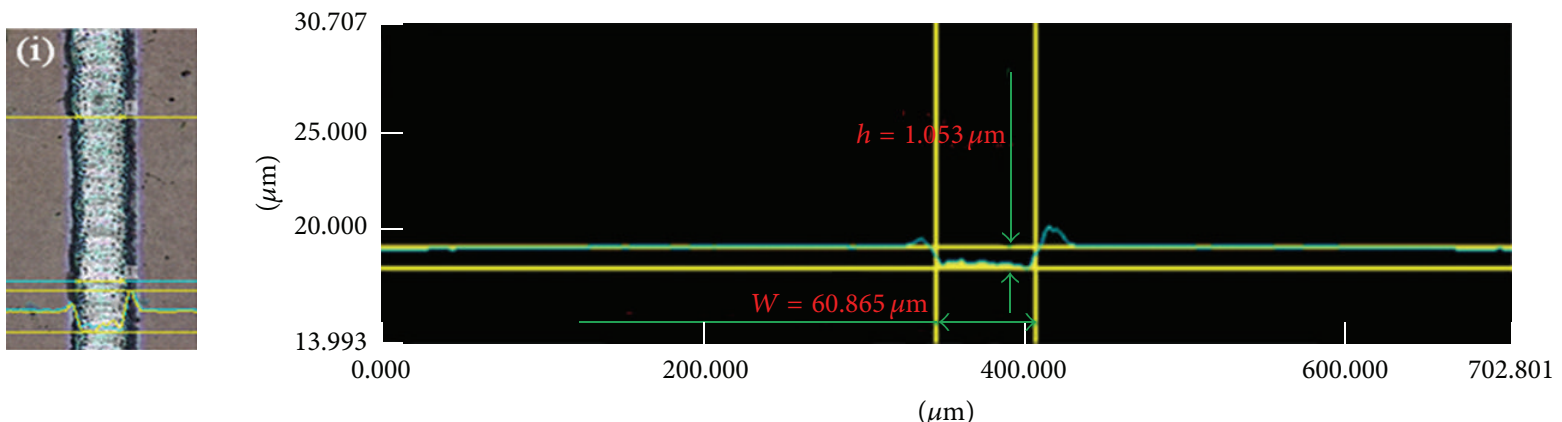

(i) $900 \mathrm{~mm} / \mathrm{s}$

FIGURE 7: Illustration of UV lasers using different scanning velocities for scribing P2 film on 3D confocal microscope. 


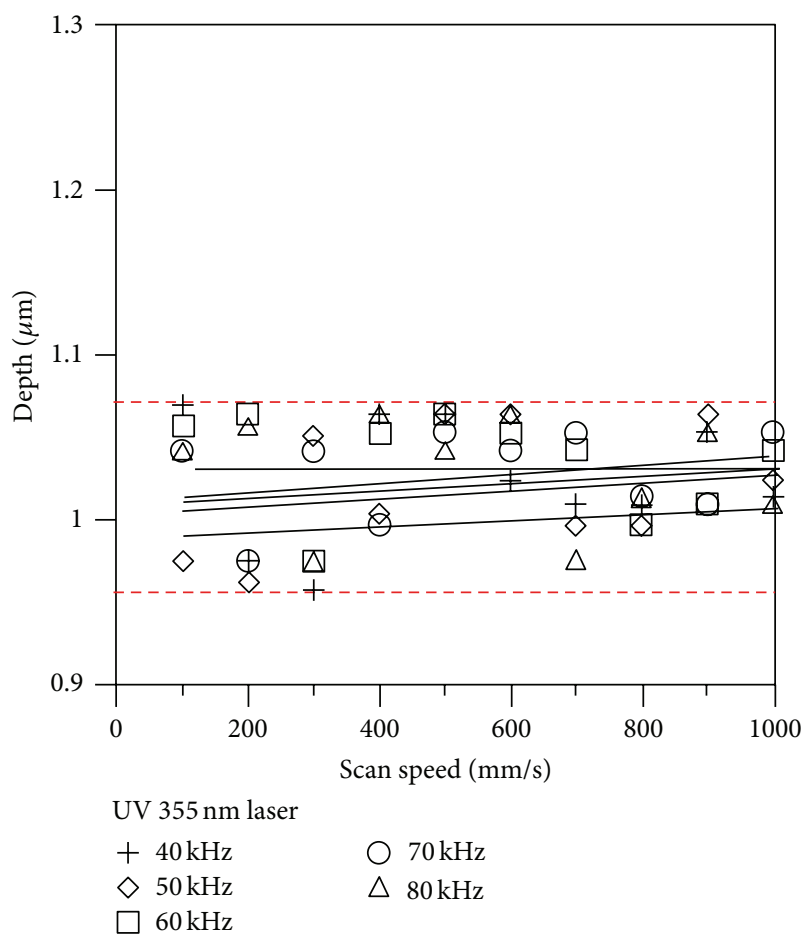

FIGURE 8: Relationship diagram of UV laser scanning velocities and underline depth.

\section{References}

[1] M. A. Ehsan, M. Khizar, M. Y. Raja, and D. Mei, "Numerical analysis of a-Si/c-Si $i_{1-x} \mathrm{Ge}_{x} / \mathrm{c}$-Si heterostructures based on $\mathrm{Si}$ and Ge thin-film solar cells," Arabian Journal for Science and Engineering, vol. 39, no. 7, pp. 5347-5353, 2014.

[2] R. Mahmoudi, M. S. Hosseinzade, E. Safari, and K. Mardani, "Continuous-wave laser treatment of egg: effects on structural and some physicochemical properties of egg's white protein," Arabian Journal for Science and Engineering, vol. 39, no. 9, pp. 6743-6747, 2014.

[3] G. S. Pisarenko and V. G. Pisarenko, "Some problems of nonlinear mechanics in geophysics, planetology, and strength of materials," Strength of Materials, vol. 32, no. 5, pp. 462-475, 2000.

[4] A. Jafari, Z. Ghoranneviss, A. S. Elahi, M. Ghoranneviss, N. F. Yazdi, and A. Rezaei, "Effects of annealing on TiN thin film growth by DC magnetron sputtering," Advances in Mechanical Engineering, vol. 6, Article ID 373847, 6 pages, 2014.

[5] M. Li, H. Shen, L. Zhuang, D. Chen, and X. Liang, " $\mathrm{SiO}_{2}$, antireflection coatings fabricated by electron-beam evaporation for black monocrystalline silicon solar cells," International Journal of Photoenergy, vol. 2014, Article ID 670438, 5 pages, 2014.

[6] A. W. Walker, F. Bouchard, A. H. Trojnar, and K. Hinzer, "Inverted metamorphic III-V triple-junction solar cell with a $1 \mathrm{eV} \mathrm{CuInSe} \mathrm{e}_{2}$ bottom subcell," International Journal of Photoenergy, vol. 2014, Article ID 913170, 10 pages, 2014.

[7] D. Patidar, A. Kaswan, N. S. Saxena, and K. Sharma, "Monodispersed $\mathrm{ZnO}$ nanoparticles and their use in heterojunction solar cell," The Scientific World Journal, vol. 2013, Article ID 260521, 6 pages, 2013.
[8] S. Zhao and C. Zhao, "Nanoscale strain fields research of boundaries between B2 matrix and G.P. Zone in Ni-Ti alloy thin films," The Scientific World Journal, vol. 2014, Article ID 127032, 5 pages, 2014.

[9] C. F. Hsu, R. K. Li, H. Y. Kang, and A. H. I. Lee, "A systematic evaluation model for solar cell technologies," Mathematical Problems in Engineering, vol. 2014, Article ID 542351, 16 pages, 2014.

[10] J. C. Huang, C. S. Xue, G. J. Zhang, and X. M. Zhan, “The study on the fabrication of nanostructure and nanomold by nanooxidation and hydrofluoric acid etching on TiAlN thin film," Journal of the Chinese Society of Mechanical Engineers, vol. 34, no. 4, pp. 353-359, 2013.

[11] H. A. Krishna, N. K. Misra, and M. S. Suresh, "Use of solar cells for measuring temperature of solar cell blanket in spacecrafts," Solar Energy Materials \& Solar Cells, vol. 102, pp. 184-188, 2012.

[12] A. Lin and J. Phillips, "Optimization of random diffraction gratings in thin-film solar cells using genetic algorithms," Solar Energy Materials \& Solar Cells, vol. 92, no. 12, pp. 1689-1696, 2008.

[13] Y. Zhao and Y. Jiang, "Investigation of room temperature UV emission of $\mathrm{ZnO}$ films with different defect densities induced by laser irradiation," Spectrochimica Acta, Part A: Molecular and Biomolecular Spectroscopy, vol. 76, no. 3-4, pp. 336-340, 2010.

[14] M. F. Chen, Y. S. Ho, W. T. Hsiao, K. C. Huang, and Y. P. Chen, "Analysis of thermal effect on transparent conductive oxide thin films ablated by UV laser," Thin Solid Films, vol. 518, no. 4, pp. 1067-1071, 2009.

[15] Y.-T. Dai, G. Xu, and X.-L. Tong, "Deep UV laser etching of GaN epilayers grown on sapphire substrate," Journal of Materials Processing Technology, vol. 212, no. 2, pp. 492-496, 2012.

[16] D. Chen and M. Chen, "Thermal effect on a CIGS thin-film solar cell P2 layer by using a UV laser," Advances in Mechanical Engineering, vol. 6, Article ID 723136, 2014. 

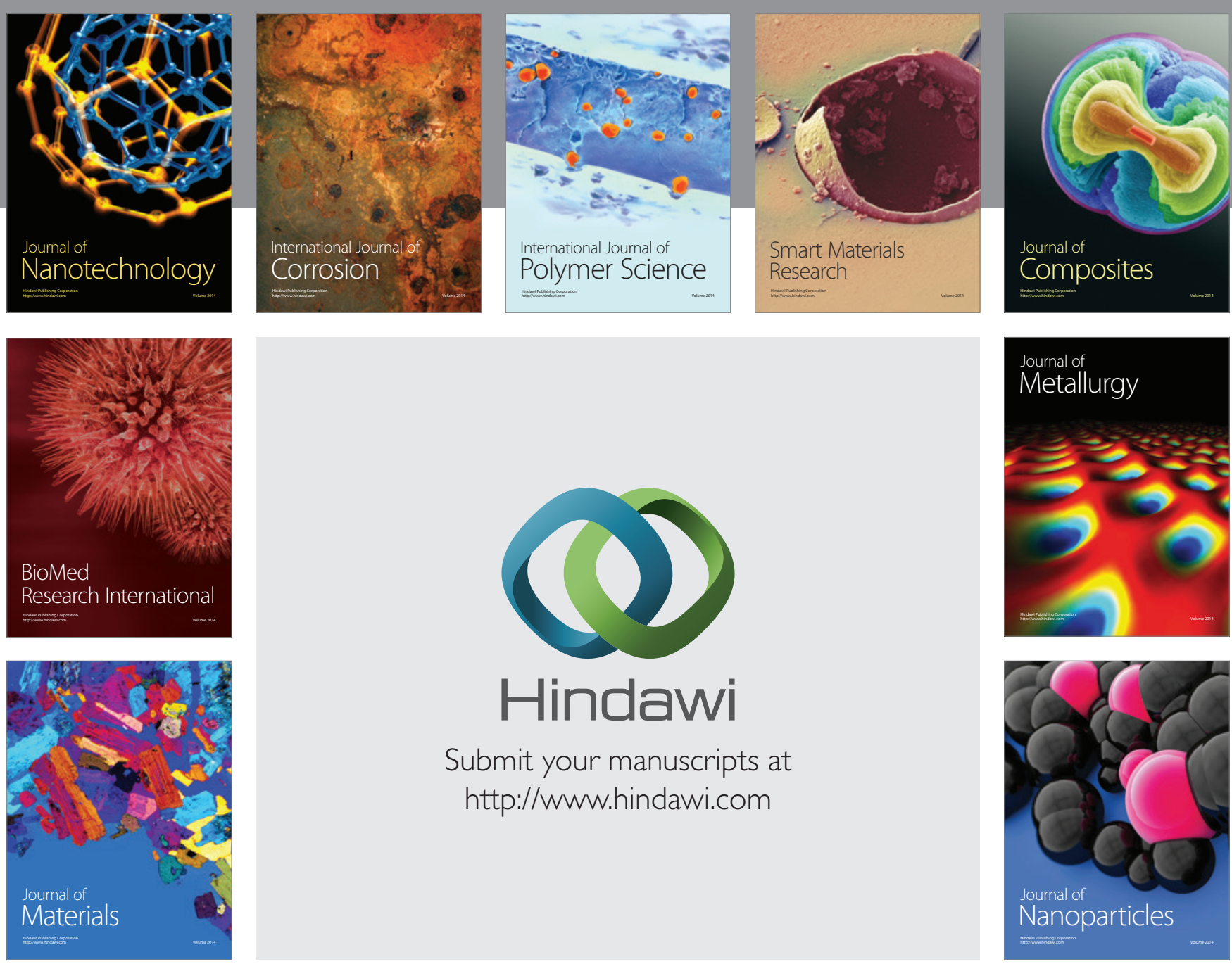

Submit your manuscripts at http://www.hindawi.com
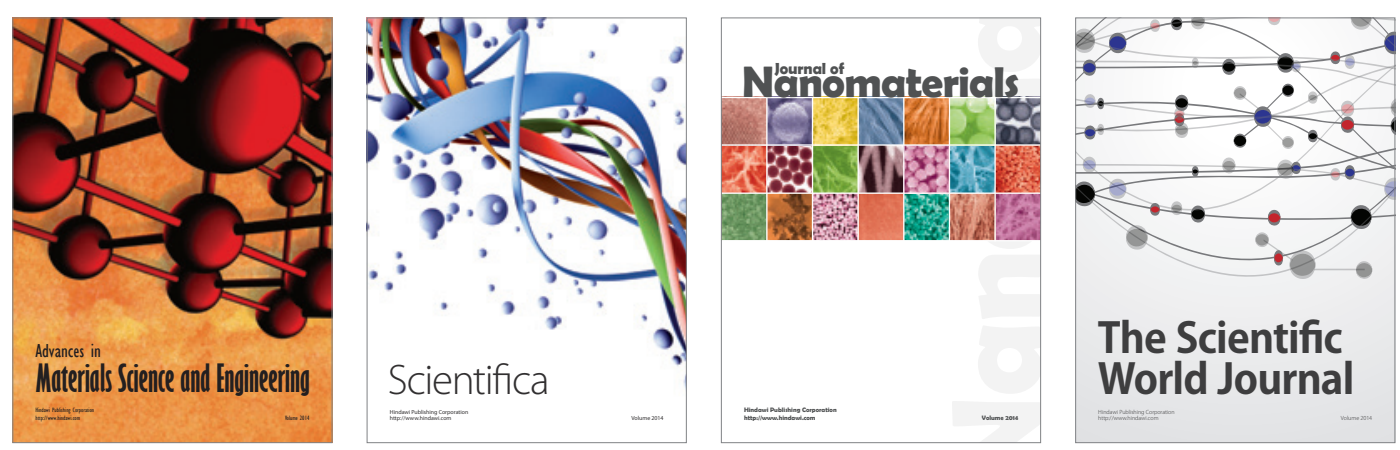

\section{The Scientific World Journal}
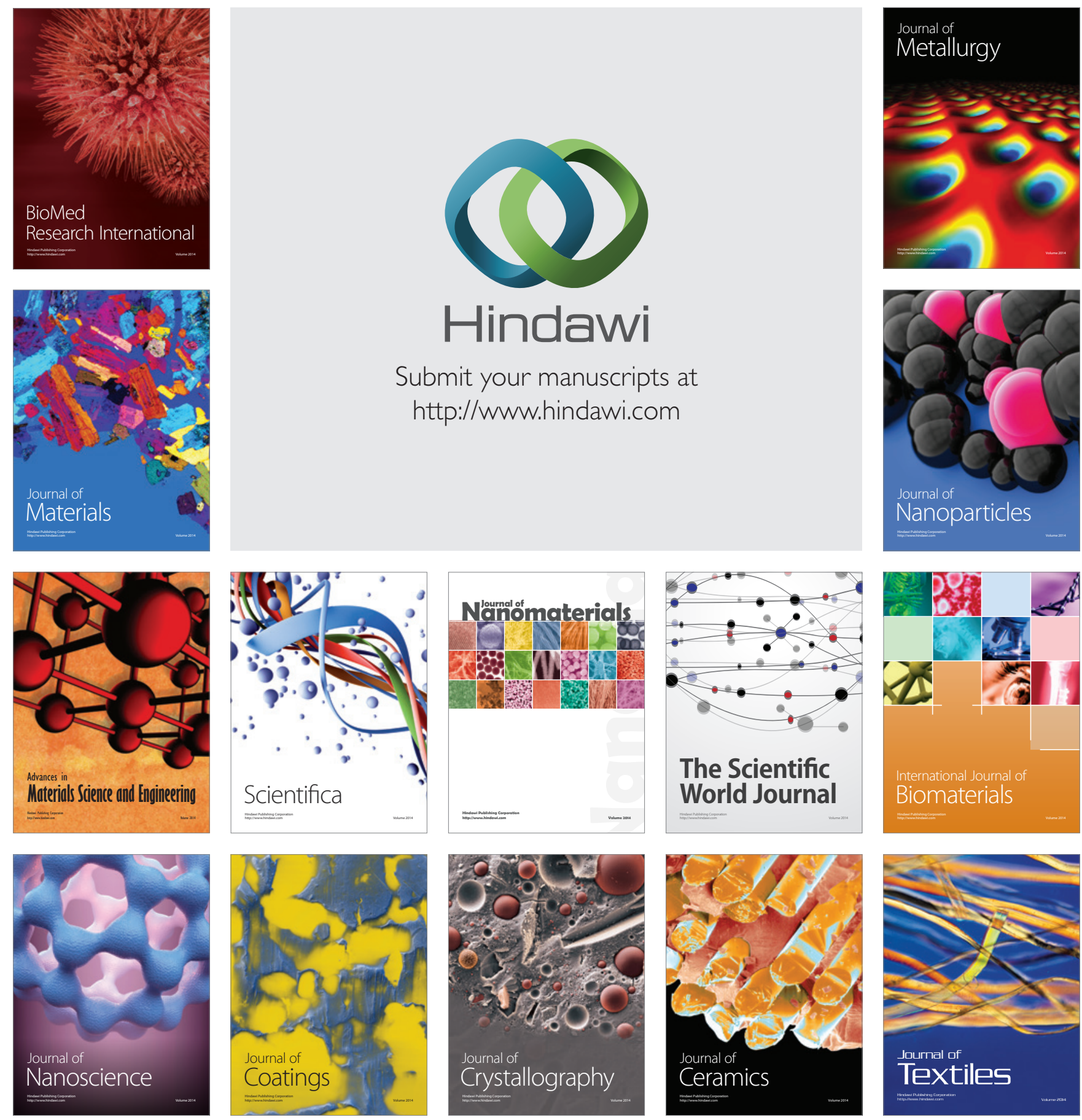